\title{
Elongated Styloid Process in Panoramic Radiographs
}

\section{Processo Estilóide Alongado nas Radiografias Panorâmicas}

\author{
Pedro Luiz de Carvalho*a; Lorena Guimarães Valente ${ }^{a}$; Larissa Victória Barbosa Freitas ${ }^{\mathrm{a}}$; João Marcelo Ferreira de \\ Medeiros ${ }^{\mathrm{b}}$; André Alencar de Lemos ${ }^{\mathrm{a}}$; Stephany Araujo da Silva Lobato ${ }^{\mathrm{a}}$
}

aUniversidade Federal do Pará, School of Dentistry. PA, Brazil.

${ }^{b}$ Universidade Brasil, School of Dentistry. SP, Brazil.

*E-mail: pedrolc@ufpa.br.

\begin{abstract}
The aim of this study is to evaluate the prevalence of the elongated styloid process in panoramic radiographic exams, in a subpopulation of northern Brazil in relation to age, sex and side. Panoramic radiographs were selected, and the apparent size of the styloid process was measured from the point where the styloid leaves the tympanic plate to the tip of the process. The data were analyzed using chi-square tests and variance analysis with a 5\% significance level. Approximately $30 \%$ of the elongated styloid process was observed in patients between 18 to 35 years. Of the styloid processes that measured more than $30 \mathrm{~mm}$ (elongated), 764 styloid processes (81\%) showed Type I elongation pattern, 97 styloid processes (10\%) showed Type II calcification patterns, and 85 styloid processes (9\%) showed Type III calcification patterns. The prevalence of the elongated styloid process was high, and no statistically significant correlation was found between the presence of the elongated styloid process and the variables studied.
\end{abstract}

Keywords: Bone Lengthening. Osteogenesis. Radiography, Panoramic.

\section{Resumo}

O objetivo deste estudo é avaliar a prevalência do processo estilóide alongado em exames radiográficos panorâmicos, em uma subpopulação do norte do Brasil em relação à idade, sexo e lado. Radiografias panorâmicas foram selecionadas, e tamanho aparente do processo estilóide foi medido a partir do ponto em que o estilóide deixa a placa timpânica até a ponta do processo. Os dados foram analisados por meio de testes qui-quadrado e análise de variância com nivel de significância de 5\%. Aproximadamente $73 \%$ do processo estilóide alongado foi observado em pacientes entre 18 e 53 anos ( $<<0,05$ ). Dos processos estilóides que mediram mais de $30 \mathrm{~mm}$ (alongados), 543 processos estiloide (82,9\%) mostraram padrão de alongamento do Tipo I, 33 processos estiloide (5,03\%) mostraram padrões de calcificação do Tipo II, e 79 processos estilóide (12,06\%) mostraram padrões de calcificação do Tipo III. A prevalência do processo estilóide alongado foi alta e não foi encontrada correlação estatisticamente significante entre a presença do processo estilóide alongado e as variáveis estudadas.

Palavras-chave: Alongamento Ósseo. Osteogênese. Radiografia Panorâmica.

\section{Introduction}

The styloid process (SP) is a bone projection of the petrous part of the temporal bone, projecting downwards, forwards, and slightly medial. Symptomatic SP elongation is also known as Eagle syndrome and causes cervicofacial pain, tinnitus and otalgia.

Stylohyoid seems to be the main ligament involved in the pathophysiology of Eagle syndrome. The ligament may be partially represented by bone, more often at its proximal end, or in some cases may be completely ossified. The topographic anatomy of the parapharyngeal space emphasizes the importance of SP length and angulation, since a possible compression and impact of the surrounding structures may appear in cases of SP elongation and/or ligaments ossification. On the other hand, muscles and ligaments fixed to the SP regulate the movements of the jaw, hyoid bone, tongue and pharyn $x^{1}$. The mineralization/ossification of the stylohyoidstylomandibular ligament complex is relatively common and can affect the function of the masticatory organ.

Several of the symptoms attributed to elongated SP are common clinical manifestations of temporomandibular joint dysfunction and, because of this overlap, there is always a potential for misdiagnosis ${ }^{2}$. Vague facial pain, especially when swallowing, turning the head or opening the mouth, dysphagia, otalgia, headache and dizziness have been associated with elongated SPs or mineralized stylohyoid ligaments ${ }^{3}$. SP varies widely in length, thickness, shape and form ${ }^{4,5}$.

The length of the styloid process has already been studied in several modalities of imaging examinations such as: panoramic radiography, lateral cephalometric ${ }^{6}$, anteroposterior cranial, computed tomography ${ }^{7}$ and anatomical methods with measurements in skulls ${ }^{1}$.

In the Brazilian population, most of the studies were carried out with panoramic radiography, to evaluate the length of the styloid process ${ }^{8-15}$. Due to the availability of the exam, diagnostic performance, low cost, lower radiation dose and 
the sensitivity of the method in the detection of styloid process elongation, this modality was preferred ${ }^{8}$.

The purpose of the study was to evaluate the prevalence of the elongated styloid process in digital panoramic radiographs, in a subpopulation of northern Brazil in relation to age, sex and side.

\section{Material and Methods}

The Research Ethics Committee of the Institute of Health Sciences of the Federal University of Pará - ICS/UFPA, Brazil, approved this study. Opinion Number: 4.003.533.

It is characterized as a descriptive-retrospective study of panoramic radiographs of 779 patients (476 women and 303 men), aged between 4 and 80 years (mean $=30.88$ years, standard deviation $=18.84)$, carried out between the years 2018 and 2019.

The radiographic images were generated using the Eagle device (Dabi Atlante, Ribeirão Preto - SP, Brazil). The X-ray settings were a 210-mm CDTE sensor with a resolution of 254 $\mu \mathrm{m} /$ pixel, a $60-85 \mathrm{kV}$ tube voltage and a $10 \mathrm{~mA}$ current with 10.5-14 seconds exposure time. The average magnification factor reported by the manufacturer was $1: 1.2$.

The panoramic radiographs with questionable styloid process, with positioning and magnification errors, with normal anatomical structures overlapped, and/or absence of age without the possibility of estimation, were excluded from the study. It was decided to divide the sample into four different age groups: Patients under 18 years old, patients between 18 and 35 years old, between 36 and 53 and, finally, patients over 53 years old.

The study was conducted in two phases: (I) preparatory phase: the evaluator training and pilot study; (II) data collection phase: evaluation of radiographic images and data annotation: name, gender, age, detection, and measurements of SP.

In the pilot phase, a researcher with experience in image exam evaluation selected 100 panoramic radiographs at random, which were examined by the evaluator using a blind approach, without the possibility of assessing age and sex. Next, Kappa statistics was applied for intra-observer concordance in the SPs detection, and to validate the method, and the intra-class correlation coefficient to verify the intraobserver concordance in relation to the SPs measurements.

The radiographic images interpretations were performed in a darkened environment for better visualization. A previously calibrated examiner using a 32-inch screen computer with Windows 10 operating system performed the digital radiographs analysis. The styloid process was measured from the point where the styloid left the tympanic plate at the tip of the process, regardless of whether the styloid process was segmented or not, and the one measuring more than 30 mm was considered elongated ${ }^{16}$. The measurements were performed with Adobe Photoshop CS image manipulation software ruler (with magnification and manipulation of brightness and contrast features) that was set to 1 pixel corresponding to 1 millimeter on the radiographs displayed on the monitor. The types of elongation were determined for the right and left styloid processes, based on the classification proposed by Langlais et al. ${ }^{4}$.

The data were typed in Excel 2010 (Microsoft, Remond, WA, USA). The statistical analyses were performed with the statistical software Jamovi (versão 1.1.9; Oxford, United Kingdom) and included frequency distribution and cross tabulation. The data were analyzed using chi-square test, with significance level established at 5\%.

\section{Results and Discussion}

The reproducibility study was performed to verify the intra-observer concordance, and the presence of SP, the Kappa value was $\mathrm{k}=0.8034$ (substantial agreement) and showed a good intra-observer concordance according to the standards proposed by Landis and $\mathrm{Koch}^{17}$. Regarding the measurements, the intra-class correlation coefficient was 0.9175 , considered excellent.

A total of 486 panoramic radiographs (62\%) were suggestive of elongated styloid process. No statistically significant difference was found between genders, although a higher prevalence was observed in female participants.

Approximately $30 \%$ of the elongated styloid process was observed in patients between 18 to 35 years. Four hundred and seventy-six exams suggest elongated SPs on right and left sides (Table 1).

Table 1 - Prevalence of the elongated styloid process, according to sex, age and side

\begin{tabular}{|c|c|c|c|c|c|}
\hline & \multicolumn{4}{|c|}{ Styloid process } & \multirow{3}{*}{$p$} \\
\hline & \multicolumn{2}{|c|}{ Unilateral } & \multicolumn{2}{|c|}{ Bilateral } & \\
\hline Sex & $\mathbf{N}$ & $\%$ & $\mathbf{N}$ & $\%$ & \\
\hline Female & 4 & 60 & 298 & 62.61 & \multirow{2}{*}{0,145} \\
\hline Male & 6 & 40 & 178 & 37.39 & \\
\hline \multicolumn{6}{|l|}{ Age } \\
\hline$<18$ & 0 & 0 & 45 & 9.45 & \multirow{4}{*}{0.135} \\
\hline $18-35$ & 5 & 50 & 208 & 43.70 & \\
\hline $36-53$ & 3 & 30 & 127 & 26.68 & \\
\hline$>53$ & 2 & 20 & 96 & 20.17 & \\
\hline
\end{tabular}

Source: Research data.

The sample data do not indicate statistical evidence that the elongated styloid process is related to sex and age $\mathrm{p}>0.05$, that is, women and men respond in the same way.

Of the styloid processes that measured more than $30 \mathrm{~mm}$ (elongated), 764 styloid processes (81\%) showed Type I elongation pattern, 97 styloid processes (10\%) showed Type II calcification patterns, and 85 styloid processes (9\%) showed Type III calcification patterns (Table 2). 
Table 2 - Prevalence of the elongated styloid process, according to sex, age, and side

\begin{tabular}{|l|c|c|c|c|c|c|}
\hline & \multicolumn{6}{|c|}{ Styloid process } \\
\hline & \multicolumn{2}{|c|}{ Type I } & \multicolumn{2}{c|}{ Type II } & \multicolumn{2}{c|}{ Type III } \\
\hline Sex & $\mathbf{N}$ & $\mathbf{\%}$ & $\mathbf{N}$ & $\mathbf{\%}$ & $\mathbf{N}$ & $\mathbf{\%}$ \\
\hline Female & 463 & 60.60 & 70 & 72.16 & 59 & 69.41 \\
\hline Male & 301 & 39.40 & 27 & 27.84 & 26 & 30.59 \\
\hline Age & & & & & & \\
\hline$<18$ & 69 & 9.03 & 10 & 10.31 & 10 & 11.76 \\
\hline $18-35$ & 334 & 43.72 & 42 & 43.30 & 38 & 44.71 \\
\hline $36-53$ & 210 & 27.49 & 23 & 23.71 & 17 & 20.00 \\
\hline$>53$ & 151 & 19.76 & 22 & 22.68 & 20 & 23.53 \\
\hline
\end{tabular}

Source: Research data.

In the present study, digital panoramic imaging of patients was used for the identification of elongated styloid process. The study emphasized the effect of age and sex on the length and elongation patterns of the styloid process. The motivation for the study was the data contribution about the prevalence of the elongated styloid process in the Brazilian population, in the northern region of the country. Of the studies already carried out, with the use of panoramic image exams, the Brazilian Southeast region is the one that has more studies on the subject, followed by the South, Northeast and Center-West region.

The use of panoramic imaging exams is considered an important diagnostic tool for the styloid process elongation ${ }^{16,18}$, as it is a simple procedure to obtain, of routine use in dentistry, and presents an overview of the maxillomandibular complex ${ }^{13}$. However, precautions should be taken when performing and analyzing the images, taking care to stabilize the degree of distortion and magnification inherent in the technical procedure and equipment. An evaluation of imaging exams associated with a careful clinical examination is mandatory in the structuring of a correct differential diagnosis and the establishment of an adequate therapeutic protocol ${ }^{16}$.

In the studies performed, several methods of styloid process measurement were used, some with analog radiographic equipment and the use of tweezers and manual rulers for direct measurement in imaging exams. In the present study, the method used was a digital tool for image measurements, like the studies of Lins et al. ${ }^{14}$, More, Asrani ${ }^{18}$ and Gracco et al. ${ }^{19}$.

The elongation of the styloid process is a frequent condition, and its prevalence has been studied in several populations around the world ${ }^{8,20}$; most cases are not associated with clinical symptoms. Some studies have shown that its occurrence in panoramic imaging exams varies greatly between $4 \%$ and $84.4 \%{ }^{12,14,22}$. In the present study, the observed prevalence was $62 \%$. There was no significant predilection of this change between genders, contrasting with the reports by More, Asrani ${ }^{18}$, Shaik et al. ${ }^{20}$, Sudhakara et $\mathrm{al}^{21}$, who identified a higher prevalence of elongated styloid process in the male gender.

Among the age groups there was no statistical difference in the prevalence of styloid process elongation, but there was a higher concentration in the group with ages between 18 and 35 years. In this respect, the studies of More, Asrani ${ }^{18}$, Anbiaee e Javadzadeh ${ }^{23}$, and Ekici et $\mathrm{al}^{24}$ reported that the length of this structure was associated with age. For the authors, this phenomenon is caused by age-related factors, such as the ligament complex degeneration and the tendency to deposit calcium salts. In this study, although there are no statistically significant differences in the type of calcification, it was observed that type II (pseudoarticulated) presents slightly longer lengths, with bilateral occurrence like other studies $^{3,12-14,20}$.

The standardization of participants regarding medical and dental history, racial characteristics, facial biotype, environmental influences, eating habits and socioeconomic factors could not be established in this study. Thus, care is needed when comparing the prevalence among different methodologies used, due to the absence of a standard in the definition of age groups, as well as the analysis of the images studied.

As far as we know, this is the first study in terms of the prevalence of the elongation and calcification patterns of the styloid process in the northern region of Brazil. More studies are still needed to evaluate the presence of the styloid process and to investigate the relationship between the type of styloid process and the symptomatic presentation (Eagle syndrome) in patients.

\section{Conclusion}

The prevalence of the elongated styloid process was high and no statistically significant correlation was found between the presence of the elongated styloid process and the variables studied. The study showed that it is possible to diagnose SP elongation by panoramic radiographic examination, however, investigations using other imaging methods, such as ConeBeam Computed Tomography, with higher number of participants, should be performed.

\section{References}

1. Natsis K, Repousi E, Noussios G, Papathanasiou E, Apostolidis S, Piagkou M. The styloid process in a Greek population: an anatomical study with clinical implications. Anat Sci Int 2015;90(2):67-74. doi: https://doi.org/10.1007/ s12565-014-0232-3

2. Zaki HS, Greco CM, Rudy TE, Kubinski JA. Elongated styloid process in a temporomandibular disorder sample: prevalence and treatment outcome. J Prosthet Dent 1996;75(4):399-405. doi: https://doi.org/10.1016/s0022-3913(96)90032-3

3. Correll RW, Jensen JL, Taylor JB, Rhyne RR. Mineralization of the stylohyoid-stylomandibular ligament complex. A radiographic incidence study. Oral Surg Oral Med Oral Pathol 1979;48(4):286-91. doi:https://doi.org/10.1016/00304220(79)90025-2

4. Langlais RP, Miles DA, Van Dis ML. Elongated and mineralized stylohyoid ligament complex: a proposed classification and report of a case of Eagle's syndrome. Oral 
Surg Oral Med Oral Pathol 1986;61(5):527-32. doi: https:// doi.org/10.1016/0030-4220(86)90400-7

5. Jung T, Tschernitschek H, Hippen H, Schneider B, Borchers L. Elongated styloid process: when is it really elongated? Dentomaxillofac Radiol 2004;33(2):119-24. doi: https://doi. org $/ 10.1259 / \mathrm{dmfr} / 13491574$

6. de Andrade KM, Rodrigues CA, Watanabe PCA, Mazzeto MO. Styloid process elongation and calcification in subjects with tmd: clinical and radiographic aspects. Braz Dent J 2012;23(4):443-50. doi: https://doi.org/10.1590/s010364402012000400023

7. Murtagh RD, Caracciolo JT, Fernandez G. CT findings associated with Eagle syndrome. AJNR Am J Neuroradiol 2001;22(7):1401-2.

8. Vieira EM, Guedes OA, Morais SD, Musis CR, Albuquerque PA, Borges ÁH. Prevalence of elongated styloid process in a central brazilian population. J Clin Diagn Res 2015;9(9):ZC90ZC92. doi: https://doi.org/10.7860/JCDR/2015/14599.6567

9. Scaf G, Freitas D, Loffredo L. Diagnostic reproducibility of the elongated styloid process. J Appl Oral Sci 2003;11(2):1204. doi: https://doi.org/10.1590/s1678-77572003000200007

10. Rovani G, Flores ME, Damian MF, Conto F. Prevalência da Síndrome de Eagle na Faculdade de Odontologia da UPF. Rev Méd HSVP 2004;16(35):12-4.

11. Rizzatti-Barbosa CM, Ribeiro MC, Silva-Concilio LR, Di Hipolito O, Ambrosano GM. Is an elongated stylohyoid process prevalent in the elderly? A radiographic study in a Brazilian population. Gerodontology 2005;22(2):112-5. doi: https://doi.org/10.1111/j.1741-2358.2005.00046.x

12. Tavares HCF, Freitas CF. Prevalência do alongamento do processo estilóide do temporal e calcificação do ligamento estilo-hióideo, por meio da radiografia panorâmica. Rev Odontol Unicid 2007;19(2):188-200.

13. Guimarães AGP, Cury SEV, Silva MBF, Junqueira JLC, Silva SCM. Prevalência do prolongamento do processo estilóide e/ ou calcificação do ligamento estilo-hióideo em radiografias panorâmicas. RGO 2010;58(4):481-5.

14. Lins CC, Tavares RM, da Silva CC. Use of digital panoramic radiographs in the study of styloid process elongation. Anat Res Int 2015;2015:474615. doi: https://doi. org/10.1155/2015/474615

15. Vieira KCL, Neto OI, Porto UN, Rodrigues CRT, Nascimento GAN, Barbosa OLC. Calcificação do ligamento estilohioideo em radiografias panorâmicas. Braz J Surg Clin Res 2018;23(2):18-23.

16. Ilgüy M, Ilgüy D, Güller N, Bayirli G. Incidence of the type and calcification patterns in patients with elongated styloid process. J Int Med Res 2005;33(1):96-102. doi: https://doi. org/10.1177/147323000503300110

17. Landis J, Koch G. The measurement of observer agreement for categorical data. Biometrics 1977;33(1):159-74.

18. More CB, Asrani MK. Evaluation of the styloid processon digital panoramic radiographs. Indian J Radiol Imaging 2010;20(4):261-5. doi: https://doi.org/10.4103/09713026.73537

19. Gracco A, De Stefani A, Bruno G, Balasso P, AlessandriBonetti G, Stellini E. Elongated styloid process evaluation on digital panoramic radiograph in a North Italian population. J Clin Exp Dent 2017;9(3):e400-e404. doi: https://doi. org/10.4317/jced.53450

20. Shaik MA, Naheeda, Kaleem SM, Wahab A, Hameed S. Prevalen-ce of elongated styloid process in Saudi population of Aseer region. Eur J Dent 2013;7-449. doi: https://doi. org/10.4103/1305-7456.120687

21. Sudhakara Reddy R, Sai Kiran Ch, Sai Madhavi N, Raghavendra MN, Satish A. Prevalence of elongation and calcification patterns of elongated styloid process in South India. J Clin Exp Dent 2013;5(1):30-5. doi: https://doi. org/10.4317/jced.50981

22. Leite HF,Niccoli Filho WD,Liberti EA,Madeira MC,Simões S. Prevalence of elongated styloid process in human skulls. Rev Odontol UNESP 1988;17(1):145-51.

23. Anbiaee N, Javadzadeh A. Elongated styloid process: Is it a pathologic condition? Indian J Dent Res 2011;22:673-7. doi: https://doi.org/10.4103/0970-9290.93455

24. Ekici F, Tekbas G, Hamidi C, Onder H, Goya C, Cetincakmak $\mathrm{MG}$, et al. The distribution of stylohyoid chain anatomic variations by age groups and gender: an analysis using MDCT. Eur Arch Otorhinolaryngol 2013;270(5):1715-20. doi: https://doi.org/10.1007/s00405-012-2202-5. 